\section{SOI: 1.1 TAS DOI: 10.15863 /TAS International Scientific Journal Theoretical \& Applied Science}

Sergey Iosifovich Tatarinov candidate of historical Sciences, associate Professor, Educational and Scientific Professional Pedagogical Institute of Ukrainian Engineering and Pedagogical Academy brodiaga-art@ukr.net

Year: $2015 \quad$ Issue: $05 \quad$ Volume: 25

Published: $30.05 .2015 \quad$ http://T-Science.org

SECTION 13. Geography. History. Oceanology. Meteorology.

\title{
PAGES FROM GORODZOV'S DIARY ABOUT BAKHMUT DISTRICT
}

Abstract: In this article letters from Uvarova and Harlamov are published, also scientist's diary about funeral traditions of Bakhmut peasants, findings of different ancients, employees' behavior during excavation, zoological observations are analyzed.

Key words: letters, tumulus, excavation, peasant.

Language: Russian

Citation: Tatarinov SI (2015) PAGES FROM GORODZOV'S DIARY ABOUT BAKHMUT DISTRICT. ISJ Theoretical \& Applied Science 05 (25): 165-168.

Soi: http://s-o-i.org/1.1/TAS*05(25)31 Doi: crossef http://dx.doi.org/10.15863/TAS.2015.05.25.31

\section{СТРАНИЦЫ ДНЕВНИКОВ И ПЕРЕПИСКИ В.А.ГОРОДЦОВА О БАХМУТСКОМ УЕЗДЕ}

Аннотация: В статье публикуются письма В.А.Городияову от П.С.Уваровой, В.А.Харламова, анализируется рукописный дневник ученого с наблюдениями о погребальном обряде крестьян Бахмутского уезда, находках разных древностей, о поведении наемных рабочих на раскопках, зоологические наблюдения.

Ключевые слова: письма, курган, раскопки, крестьянин.

В Отделе письменных источников ГИМа (Москва) хранится огромная переписка В.А.Городцова с учеными-коллегами, краеведами, иностранцами [1].

Нам удалось ввести в научный оборот письма П.С.Уваровой, А.С.Федоровского, Н.В.Сибилева, И.А.Часовникова [2-5].

2 июня 1903 года В.А. Городцов писал, что «выехал в Екатеринославскую губернию для проведения археологических раскопок курганов» [6-7].

Раскопки 1901 года он закончил у с. Селимовка (Шаховка) Изюмского уезда. Это село (ныне Кировка) примыкает с Ю3 к знаменитому с. Черногоровка (по раскопанным погребениям киммерийцев) на современной окраине г. Северск Артемовского района (в начале ХХ ст. - Яма) [8].

10 июня 1903 года В.А. Городцов осматривал поля с СВ от Ямы в Каменском участке министерства земледелия, у с. Родионовка (ныне часть Северска-Ямы) [9-10].

В.А. Городцова заинтересовало устройство прудов, плотин, их размещение, способы отвода воды Каменского орошаемого участка.

Дневник содержит любопытные заметки, что в Бахмутском уезде «повсюду кладут покойникам монеты, привязывая их к поясу». В.А. Городцов писал, что крестьяне хуторов хоронят покойников без священников, окуривают могилу ладаном в горшочках и помещают затем горшки в могилу. Священники «сыплют в могилы угли из кадила» [11].

Интересно, что наблюдение В.А. Городцова о помещении монет в могилы нашло свое подтверждение во время раскопок С.M. Дегерменджи казацкого кладбища XVIII ст. у Хайловских хуторов (с. Ильичевка, в 20 км от Ямы). У поясов покойников были медные монеты Екатерины II.

В.А. Городцов занимался не только раскопками курганов, но и собирал разные древности.

В его дневнике есть рисунок татарской глиняной курильницы XVI -XVII веков, которую ученому дали крестьяне хут. Кузьминовка. Кувшин-курильница имел ручку, биконический корпус, кольцевидный поддон и треугольные прорези по корпусу, фигурную крышку. Городцов указывал, что такая же курильница была найдена в Большой Камышевахе Изюмского уезда [11]. 
В письме 24 апреля 1903 г. председатель Московского Археологического общества П.С.Уварова сообщала В.А.Городцову -«пишу из Екатеринослава, куда приехала вчера вечером, проведя удачный день в Харькове...На карте, на которой вы намечали свои раскопки вероятно помещена територия вдоль левого берега Кальмиуса....Весьма возможно, что мы туда направим одного из представителей Донецкого края Василия Харламова с целью обследовать левый берег р.Кальмиус, которого правый берег будет изучен вами» [12].

По каким-то делам В.А. Городцов ездил из Бахмута в Константиновку и зарисовал половецкую статую у с. Ступки (Ближние Ступки, Ивановка - Крещенское, ныне с. Красное). Он отмечал, что «на этом пути можно видеть всего семь баб» [11].

В связи с раскопками в Бахмутском уезде началась переписка В.А.Городцова и В.А.Харламова [13].

Первое письмо В.Харламова написано В.А.Городцову 19 мая 1903 г. -«посылаю вам буклетные билеты. Ежели работы ваши в Бахмутском уезде затянутся, то билет можно будет возобновить. Относительно медицинского свидетельства я также вам устрою. Врач Бахмутской земской больницы В.М.Стебельский с охотой выдал вам все необходимые листы, лишь вам приехать к нему, обо всем с ним переговорил... Желал бы очень побывать на раскопках» [13].

Упоминаемый я письме В.М.Стебельский был известным врачом уезда, возглавлял земскую больницу в Бахмуте. Он родился в Бахмутском уезде в крестьянской семье, окончил в 1885 г. Харьковский универсчитет, работал врачом 1 и 2 участков. Был гласным городской Думы, лечил гимназистов и учеников ремесленного училиша. В 1905 г. помогал революционерам, лечил раненых солдат 1-й Мировой войни, «белых» и «красных», боролся с тифом и во время эпидемии в 1920 г. умер. Как писала газета «Приднепровский край» (30.12.1912 г.) « по инициативе доктора открылся шахматный кружок». В 1914 г Екатеринославский губернатор не утвердил проект Устава «Бахмутского шаматного общества» и отказал окончательно в июне 1915 г. До 1917 г. В.М. Стебельскому не было равных по шахматам ни в Бахмуте, ни в губернии [14].

25 мая 1903 г. В.Харламов пишет, что «с большой радостью узнал от графини Прасковьи Сергеевны, что командирован от московского археологического общества для исследования левого берега реки
Кальмиуса в пределах Донской области. Для меня очень важно то, что я буду работать под вашим руководством. Я Давно хотел этого. Мне общество ассигновало на раскопки 400 р, вам назначили 1000 р. Мне бы очень хотелось перед отьездом из Москвы узнать от вас о времени вашего выезда и условиться о месте и времени встречи, чтобы на месте я мог получить ваши указания относительно плана работ. Может быть вы найдете возможным написать мне теперь о том, что вы предполагаете делать и по какому плану думаете вести свои раскопки. Как устроились насчет рабочих и протчее. В Москве я пробуду до 26-27 мая, 25 мая будет мое венчание. Потом сьезжу на неделю в Киев к родителям жены, а потом поеду на Дон.Графиня еще просила зайти к ней по возвращению из Можайска переговорить об условиях командировки. Мне неудобно спрашивать у ней форму отчетности...может вы просветите на сей счет...Адрес мой Москва, Воскресенский проезд, дом Сретенского, кв.8. Летний адрес ОВД, станица Екатерининская 1 округа, киевский адрес Печерск, Московская, 15, кв.2» [13].

29 мая В.Харламов писал,что «семейные мои обстоятельства так сложились, что не мог зайти в музей. Сегодня уезжаю с семьей в Киев. Вещи я посылаю в музей, вы их сложите до моего возвращения в августе. Вещи Сулина пожалуйста потрудитесь переслать сами- Новочеркасск, Донской музей, Ивану Михайловичу Сулину. Сообщите когда поедете на работы и в какое место.Может быть я не утерплю и заеду» [13].

Не датированным (вероятно, 1904 г.) является письмо Городцову, где Харламов пишет, что «в пятницу вас не было на заседании, не было на обеде у графини в среду. Поэтому я не мог вам передать списки своих раскопок на Кальмиусе и брошуру об аналогичных раскопках по Донцу. Самому решительно нет времени побывать у вас, ...буду на заседании в понедельник. С удовольствием жду вашего доклада» [13].

В процессе раскопок у В.А. Городцова возникла идея написать статью «Враги истории народов, обитавших в Бахмутском уезде».

Эта рукопись датируется 18 сентября 1903 года и завершена в с. Райское в имении Ф.А. Бантыша [11].

Фамилия Бантышей встречается в земских и дворянских документах уезда с середины XIX столетия. В 1883 - 1890 годах А.А. Бантыш был уездным предводителем дворян. Ф.А. Бантыш и В.А. Бантыши были членами уездной земской управы и “гласными” губернского земства в 1890 
году. В.А. Бантыш с 1888 года был почетным мировым судьей уезда.

Ф.А. Бантыш помогал В.А. Городцову вести раскопки курганов в своих имениях $\mathrm{y}$ c. Камышеваха и хут. Пески, выделил деньги.

В статье «Враги истории народов...» Городцов отмечает отрицательную роль крымских татар и русских, объединенных «одинаковым гордым невежеством, освященным религиозным фанатизмом» в уничтожении памятников археологии. Мысли ученого полны возмущением - называет грабителей «подлыми тварями», лезли в могилу «без всякого риска», темной ночью, выбрав кратчайший путь, через узкую яму добирались до сокровищ покойника, «небрежно разбрасывая его бренные останки по углам загробного жилья». Ограбление могил, по мнению В.А. Городцова, началось уже со времен катакомбной культуры, когда грабитель лишал «исторического имени самых богатых людей, уничтожал цвет современной ему культуры и цивилизации». Сколько здесь философии и даже поэзии в прозе. О поздних кладоискателях Городцов писал, что действовали они наугад, с большими трудностями, огромным размахом и уничтожали все непонятное им. «Невежество и алчность способны проделывать невероятные труды», «особенно энергично работают хохлы и шахтеры в заводских селениях» [11].

В.А. Городцов упоминает управляющего немца Кребса в имении «светлейшего Ливена», который в районе Юзовки разграбил множество курганов.

Своего рода шуткой ученого можно назвать оценку курганного грызуна бабака.

Oн предполагал, что имя «бабак» («бабашня») перешло в Бахмуте «на городских жуликов и бродяг».

Наиболее поврежденные грабителями и кладоискателями курганы Городцов встречал в южной части Бахмутского уезда. Он тщательно зарисовал разрезы так называемых «майданов», типичных грабительских и кладоискательских ям с разрушенными погребениями [11].

Раскопки в уезде, вероятно, дались Городцову нелегко. Особенно его поразили наемные рабочие - крестьяне.

Интеллигентный, просвещенный ученый в самой уничижительной форме пишет в заметке «К характеристике рабочих Бахмутского уезда», что для нанимаемых им рабочих характерны «лень, бессовестность и склонность к мошенничеству - основная черта рабочих, ... с которыми пришлось иметь дело на протяжении всего уезда... крестьяне здесь хуже бродяг». Они роптали - утром на тяжелый труд, ругали за плохие харчи. Договорившись с вечера, не выходили на работу утром, бросали работу на второй - третий день, требовали плату не менее рубля в день, без надзора кончали работу и ложились спать, «отвечают дерзостью или принимают вид озлобленной ворчащей бродячей собаки» [11].

Городцова раздражали и возмущали постоянные отлучки рабочих «по естественной надобности». «За компанию идут по двое - трое, ... сняв штаны стараются дольше сидеть в этом гарантированном положении, однажды на наших глазах рабочий уснул в этом положении». Если рабочих посылали за ведром воды утром или лопатами, то приходили они к вечеру. «Успех работы чрезвычайно малый», так как копачи «ко всякого рода забастовкам чрезвычайно склонны», часто бросали лопаты, ругались и призывали других последовать их примеру» [11].

В.А. Городцов написал такие комментарии в Бахмутском уезде потому, что здесь было много, в отличие от Изюмского уезда, пришлых крестьян, рабочих, «перекати-поле» (хорошо описанных в романе «Беглые в Новороссии В.Данилевского), устремившихся в Донбасс или «Новую Калифорнию» по образному выражению поэта Александра Блока.

Из дневниковых записей видно, что В.А. Городцов интересовался вопросами экологии и орнитологии в современном понимании этого.

С конца августа 1903 года он постоянно наблюдал и письменно фиксировал миграции стай птиц [11].

В середине августа он наблюдал большие стаи коршунов на р. Кальмиус у хут. Лагери и Пески (прим. С.Т. - сейчас там бои АТО на окраине Донецка...) в течение двух дней, следил за большими стаями дроф (которые нынче полностью вывелись). С середины сентября он отмечает появление больших стай и поведение чибисов и грачей [11].

19 сентября записал, что «шел пролет гусей стаями по 50, молча без крика» [11].

В процессе разборки насыпей курганов В.А. Городцов наблюдал и зарисовывал следы жизни бабака, суслика, сурка, тушканчика, разных насекомых, сделал рисунок жука-курганщика [811].

Очень любопытны записи о пыльных бурях в уезде весной 1902 года, как в имении Бантыша кукурузными «кулисами» задерживали снег и препятствовали снежным бурям. Ученый даже сделал рисунок «кулис» [11].

Идея Докучаева устраивать лесополосы по полям в начале XX ст. еще не нашла поддержки.

В течение трех месяцев В.А. Городцов раскопал в Бахмутском уезде более 80 курганов (212 погребений) [9-10].

19 сентября 1903 года он отметил в дневнике чудную осеннюю погоду, а уже 20 сентября «погода заметно начала портиться, 21 сентября - дождь, 23-го в Харькове - дождь и 
ветер, 29-го в Москве - снежно, 30-го - в Ярославле снег, настоящая зима» [11].

11 октября 1903 года В.А. Городцов начинает писать отчет о финансовой деятельности: израсходовано на раскопки в Бахмутском уезде 1700 рублей, из них выделено Московским археологическим обществом 1200 рублей, заводом Джона Юза (Новороссийское общество) - 400 рублей и Ф.А. Бантышем - 100 рублей [11].

Многочисленное дворянство Бахмутского уезда и богатые купцы-промышленники Бахмута участие в раскопках В.А. Городцова не принимали. Мы нашли упоминание о выделении В.А.Городцову на раскопки 100 руб. от Бахмутской уездной земской управы.

\section{References:}

1. (1988) Nasledie V.A.Gorodtsova i problemy sovremennoy arkheologii//Trudy GIM.

Moscow, - 1988, - pp.71-72.

2. Tatarinov SI (2004) V.O.Gorodtsov ta Bakhmuts'kiy povit (listi P.S.Uvarovoï) /S.Y.Tatarinov// Pratsi Tsentru pam"yatkoznavstva NANU-UTOPIK. -Vip.6, Kiïv, -2004, - pp.99-106.

3. Tatarinov SI (2005) Neizvestnye pis'ma N.V.Sibileva V.A.Gorodtsovu/ S.I.Tatarinov// Problemy sokhraneniya istoriko-kul'turnogo naslediya. -Slavyansk-Svyatogorsk, -2005, pp.240-244.

4. Tatarinov SI (2007) V.A.Gorodtsov i professorgeolog Khar'kovskogo universiteta A.S.Fedorovskiy /S.I.Tatarinov// Pratsi Tsentru pamyatkoznavstva NANU-UTOPIK, -Kiïv, 2007, -vip.11, - pp.173-175.

5. Tatarinov SI (2007) Arkheologiya u Artemivs'komu muzeï u 20-30 rokakh/ S.I.Tatarinov//Arkheologiya,-Kiïv, -2007, - 4, s.89-90.

6. (2015) OPI GIM. - F.431. -Ed.khr.444. - Ll.114 (pis'ma P.S. Uvarovoy);

7. Tatarinov SI (2004) V.O.Gorodtsov ta Bakhmuts'kiy povit (listi P.S.Uvarovoï) /S.Y.Tatarinov// Pratsi Tsentru pam"yatkoznavstva NANU-UTOPIK. -Vip.6, Kiïv, -2004, - pp.99-106.

8. Gorodtsov VA (1905) Rezul'taty arkheologicheskikh issledovaniy v Izyumskom uezde /V.A.Gorodtsov// TRUDY XII arkheologicheskogo s"ezda v Khar'kove v 1902. -Moscow: Tovarishchestvo tipografii A.I. Mamontova, - 1905, - Tom I. -pp.174-216.

9. Gorodtsov VA (1905) Rezul'taty arkheologicheskikh issledovaniy v Bakhmutskom uezde, Ekaterinoslavskoy gubernii, 1903 goda /V.A.Gorodtsov//Trudy XIII arkheologicheskogo s"ezda V Ekaterinoslave. -1905. -Tom I. Pod redaktsiey grafini Uvarovoy. -Moscow: Tipografiya G. LISSNERA i D. SOBKO. -pp. 211-285;

10. Gorodtsov VA (1905) Dnevnik arkheologicheskikh issledovaniy. -Tam zhe, pp.286-345

11. (2015) OPI GIM. - F. 431. - Ed. khr. 327. - Ll. $165-171$.

12. (2015) OPI GIM. - F.431.-Ed.khr.444. - L1.1-14 (pis'ma P.S. Uvarovoy)

13. (2015) OPI GIM. - F.431. - Ed.khr.62.- Ll.156160 ( pis'ma V.A.Kharlamova)

14. Tatarinov SI, Zavada LV, Blednov VP (2011) Ozerki istorii zemskoy meditsiny Bakhmutskogo uezda /S.I.Tatarinov// Artemovsk, - 2011, - 86 p.

15. (2015) OPI GIM. - F. 431. - Ed. khr. 328. - L.1. $20-23$. 